\title{
БЕРИНГИЯ: СЕЙСМИЧЕСКАЯ ОПАСНОСТЬ И ФУНДАМЕНТАЛЬНЫЕ ВОПРОСЫ ГЕОТЕКТОНИКИ
}

\author{
(С) 2015 г. Е. И. Гордеев ${ }^{1}$, Т. К. Пинегина ${ }^{1}$, А. В. Ландер ${ }^{2}$, А. И. Кожурин ${ }^{1}$ \\ ${ }^{1}$ Институт вулканологии и сейсмологии РАН, г. Петропавловск-Камчатский \\ ${ }^{2}$ Институт теории прогноза землетрясений и математической геофизики РАН, г. Москва \\ E-mail: gordeev@kscnet.ru,pinegtk@yandex.ru,land@mitp.ru,anivko@yandex.ru \\ Поступила в редакцию 30.07.2013 г.
}

\begin{abstract}
В статье представлен краткий обзор существующих на сегодня взглядов на геодинамику Берингии, рассмотрено пространственное распределение сейсмичности в Камчатско-Алеутско-Аляскинском регионе, проявления цунами, известные на данный момент активные разломы на обрамлении Командорской котловины, положение коллизионного контакта в зоне сочленения Камчатской и Алеутской дуг, вероятность катастрофического землетрясения на западном окончании Алеутской дуги, сейсмо- и цунамигенерирующий потенциал Берингии.
\end{abstract}

DOI: $10.7868 / \mathrm{S} 0002333715030035$

\section{ВВЕДЕНИЕ}

Беринговоморский регион уникален по своему тектоническому положению. С юга он ограничен Алеутскими островами, с востока - побережьем Аляски, с запада и севера - Камчаткой, Корякией и Чукоткой. Регион уже много лет является объектом как российских, так и американских исследований, но по причинам географической удаленности и непродолжительности инструментальных геофизических и геодезических наблюдений изучен он все еще недостаточно. Практически неизвестен сейсмический и цунамигенный потенциал региона, остается ряд нерешенных вопросов, связанных с характером сочленения Курило-Камчатской и Алеутской дуг на его южной границе, режимом деформирования его западного и северного континентальных обрамлений. По современным представлениям, основную территорию региона занимает Берингийской плита, или плита Берингия, располагающаяся на стыке Тихоокеанской, Северо-Американской и Евразийской литосферных плит, однако до настоящего времени нет ясности не только с положением ее границ, но и с самим ее наличием. В данном обзоре представлены основные имеющиеся на сегодня сейсмологические и тектонические взгляды на Берингию и рассмотрены главные вопросы, решение которых представляется крайне важным как в научном плане, так и для оценки сейсмо- и цунамиопасности во всем регионе.

\section{ПРОСТРАНСТВЕННОЕ РАСПРЕДЕЛЕНИЕ СЕЙСМИЧНОСТИ В РЕГИОНЕ}

Беринговоморский регион окружен сейсмическими поясами по всему периметру (рис. 1). На севере, западе и юге землетрясения происходят как на суше, так и в прибрежных акваториях; во- сточное, аляскинское, побережье почти асейсмично. Обычно считается, что Берингово море полностью располагается на жесткой литосферной плите Берингии [Ландер и др., 1994; Cross, Freymueller, 2008; Mackey et al., 1997] и сейсмичность связана с движениями на ее границах. Однако за последние 20 лет в центральной части Берингова моря были зафиксированы два землетрясения с магнитудами 6.5-6.7 (с короткими сериями афтершоков). Район этих землетрясений удален от всех сейсмологических сетей, и наблюдения здесь могут быть неполными. Поэтому остается неясным, являются ли эти землетрясения частью еще одного сейсмического пояса, разделяющего Берингию, либо изолированными внутриплитными событиями. Эпицентры землетрясений, расположенные в центральной части Командорской котловины, относятся к раннему периоду наблюдений, соответствуют небольшим магнитудам и, по-видимому, попадают в этот район вследствие ошибок наблюдений.

Землетрясения западной окраины Берингова моря образуют Корякский сейсмический пояс, протягивающийся от области сочленения Курило-Камчатской и Алеутской дуг на север и смыкающийся там с сейсмическими поясами Чукотки и Аляски. Эпицентры большинства землетрясений южной части Корякского пояса располагаются на восточном камчатском шельфе, однако несколько относительно сильных событий, в том числе, возможно, и крупнейшее Озерновское землетрясение 1969 г. с $M=7.8$ произошли у подножья его континентального склона. Севернее основная активность Корякского пояса сосредоточена на суше, в центральных районах Корякского нагорья. Однако отдельные землетрясения известны здесь и в акватории вблизи корякского побережья. 


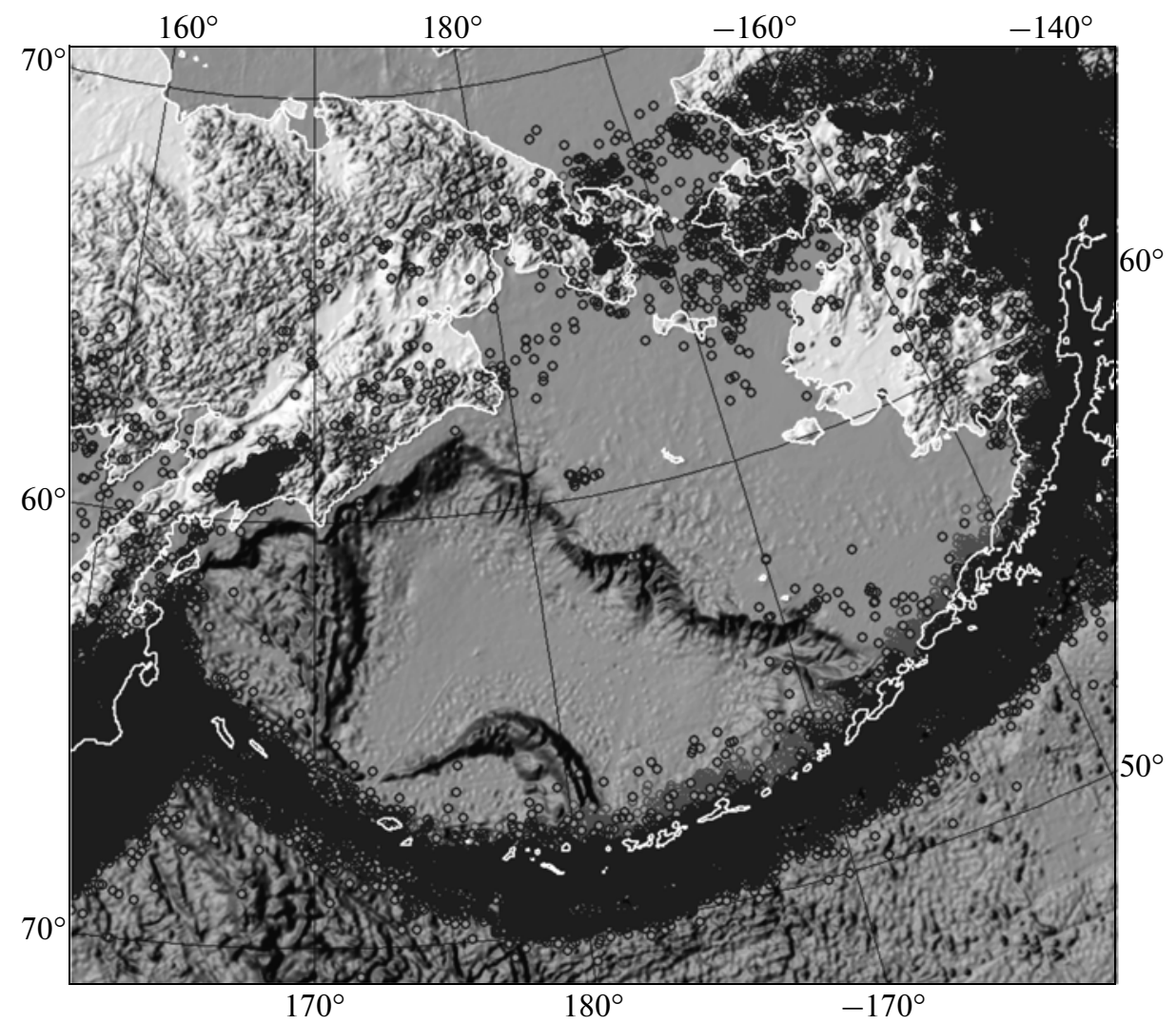

Рис. 1. Землетрясения Беринговоморского региона, зарегистрированные за период 1962-2010 гг. [Каталог...; Землетрясения в СССР; Alaska Earthquake Information Center; USGS National Earthquake Information Centre; Bulletin...; Global CMT catalog].

Наибольшее число сильных землетрясений региона происходит в Алеутской дуге, являющейся одной из самых сейсмически активных структур Земли. В ней зарегистрированы цунамигенные землетрясения с $M \geq 9$. События дуги можно пространственно разделить на две группы. К первой относятся землетрясения, происходящие на субдукционной, переходящей западнее в трансформную, границе Тихоокеанской плиты. Именно здесь происходят сильнейшие события, эпицентры которых расположены в Тихом океане, но их протяженные очаги могут частично располагаться на глубинах $\sim 50$ км под акваториями Берингова моря. Ко второй группе относятся задуговые землетрясения с мелкофокусными гипоцентрами в Беринговом море. Эта сейсмичность, по-видимому, связана с трансформным перемещением блоков дуги вдоль ее простирания [Lallemant, Oldow, 2000; Cross, Freymueller, 2008] и имеет преимущественно сдвиговый характер. Здесь зафиксированы магнитуды до 7.5. В ту же группу задуговых землетрясений формально попадает несколько крупных событий первой половины 20-го века с низкой точностью определения гипоцентров и с $M \leq 7.9$ [Gutenberg, Richter, 1949]. Не исключено, что эти события в реальности произошли в зоне субдукции.
Особый характер имеет небольшая группа землетрясений в районе сочленения Алеутской дуги с Камчаткой. Эти события связаны с торцовым столкновением с последней крайнего западного сегмента дуги - узкого Командорского блока [Гордеев и др., 2004; Geist, Scholl, 1994; Gordeev et al., 2006; Mackey et al., 2010]. Сейсмичность района полуострова Камчатский имеет определенные отличия от каждой из двух примыкающих сейсмофокальных зон и не может быть отнесена ни к одной из них. В районе полуострова Камчатский регистрируются в основном мелкофокусные землетрясения в слое глубиной до 50 км. В Камчатском проливе землетрясения концентрируются вдоль трансформных разломов Беринга, Пикежа и Стеллера [Селиверстов, 2009]. Западнее, при переходе к шельфу полуострова Камчатский, эта закономерность нарушается, и эпицентры землетрясений занимают всю фронтальную часть Командорского блока между ограничивающими его разломами, а также южную часть полуострова. Среди механизмов землетрясений района полуострова Камчатский преобладают взбросы с субгоризонтальной осью сжатия, ориентированной С3-ЮB [Global CMT catalog]. 


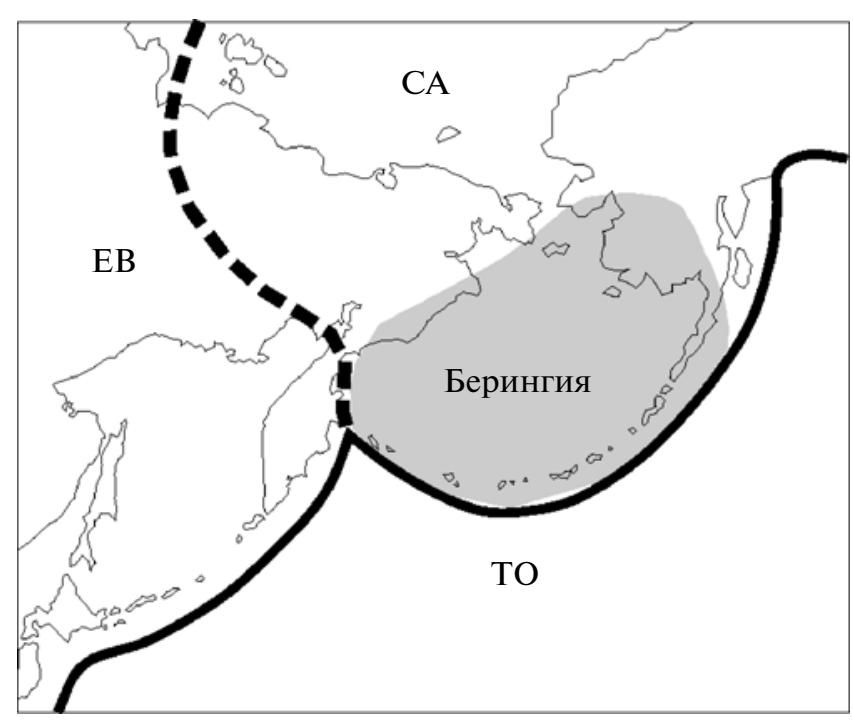

Рис. 2. Границы литосферных плит: ТО - Тихоокеанской, СА - Североамериканской, ЕВ - Евразийской. Сплошные черные линии - установленные границы, пунктирные линии - предположительные. Положение микроплиты Берингии показано серой заливкой.

\section{ЛИТОСФЕРНАЯ ПЛИТА БЕРИНГИЯ}

До настоящего времени существование плиты Берингии является предметом дискуссий [Ландер и др., 1994; Кожурин, 2012; Geist, Scholl, 1994]. Основная проблема заключается в том, что плита не имеет отчетливо выраженных в геологической структуре границ с Северо-Американской и Евразийской плитами. В связи с этим, многие исследователи продолжают включать Берингию в состав Североамериканской плиты (рис. 2). В работе [Scholl, 2007; Redfield et al., 2007] предполагается, что Берингия состоит из большого числа независимых блоков, участвующих в общем “потоке", движущемся за счет экструзивного выжимания масс Аляски и Берингии на запад или юго-запад. Хотя существование таких блоков не доказано, их перемещения относительно Северо-Американской плиты могут грубо описываться единым вектором вращения, который в первом приближении можно считать вектором вращения Берингии.

Параметры движения Берингии остаются дискуссионными. Их оценки в основном опираются на два типа данных: механизмы землетрясений и геодезические измерения (GPS) [Гордеев и др., 2001; Gordeev et al., 2001], часто противоречащие друг другу.

С общим вращением Берингии можно увязать механизмы землетрясений только на ее северной континентальной границе. На южной, алеутской, границе векторы относительных перемещений определяются быстрыми движениями Тихоокеанской плиты и их направления практически мало меняются при выборе той или иной модели медленного вращения Берингии. Иначе говоря, механизмы алеутских землетрясений в пределах своей точности не несут значимой информации о движении Берингии. Основные выводы о параметрах ее вращения следуют из закономерного изменения механизмов вдоль ее северо-западной границы: от сжатия на юге Корякии, к сдвигам на Чукотке и растяжению на северо-западе Аляски (рис. 3). Такое расположение механизмов соответствует положению полюса вращения Берингии относительно Северной Америки северо-западнее их границы. Более определенное положение полюса можно получить, если предположить, что Берингия "скользит" вдоль восточного сегмента Алеутской дуги, не вызывая смещения расположенной там зоны субдукции (рис. 3). При этом следует отметить, что положение границы Берингии на Аляске остается крайне неопределенным: в том виде, как показано на рис. 3, она проходит поперек крупнейших активных сдвигов Аляски (например, поперек разлома Денали).

Геодезические измерения в регионе затруднены тем, что практически все районы Берингии, расположенные выше уровня моря, относятся к граничным тектонически нестабильным областям рассеянной сейсмичности. Поэтому локальные геодезические измерения могут быть весьма чувствительны к движениям небольших блоков, не совпадающим с общим движением плиты. Тем не менее, геодезические данные, полученные на северо-западе Аляски [Cross, Freymueller, 2008], подтверждают южное направление движения этой части Берингии. Однако при определении положения полюса вращения Берингии относительно Северной Америки эти авторы использовали также алеутские GPS-измерения, возможно, искаженные деформациями висячего блока зоны субдукции. В результате, полученный ими полюс оказался в Приамурье, при этом параметры движения противоречат данным о механизмах землетрясений Корякии. В связи с этим, оценки вращения Берингии по данным GPS-измерений пока не могут считаться приемлемыми.

Северная граница Берингии проводится по Корякскому сейсмическому поясу [Ландер и др., 1994; Mackey, 2010]. Широкая полоса редкой (если исключить афтершоки) рассеянной сейсмичности охватывает практически все Корякское нагорье, продолжаясь на север через Анадырский залив и Чукотский п-ов к Аляске, а на юг, вдоль камчатского шельфа, - к области сочленения Алеутской дуги и Камчатки. Подавляющее большинство землетрясений пояса происходит в пределах окраины континента и прилегающего шельфа. Лишь единицы из числа надежно определенных эпицентров землетрясений Корякского пояса располагаются в пределах океанических котловин Берингова моря. 


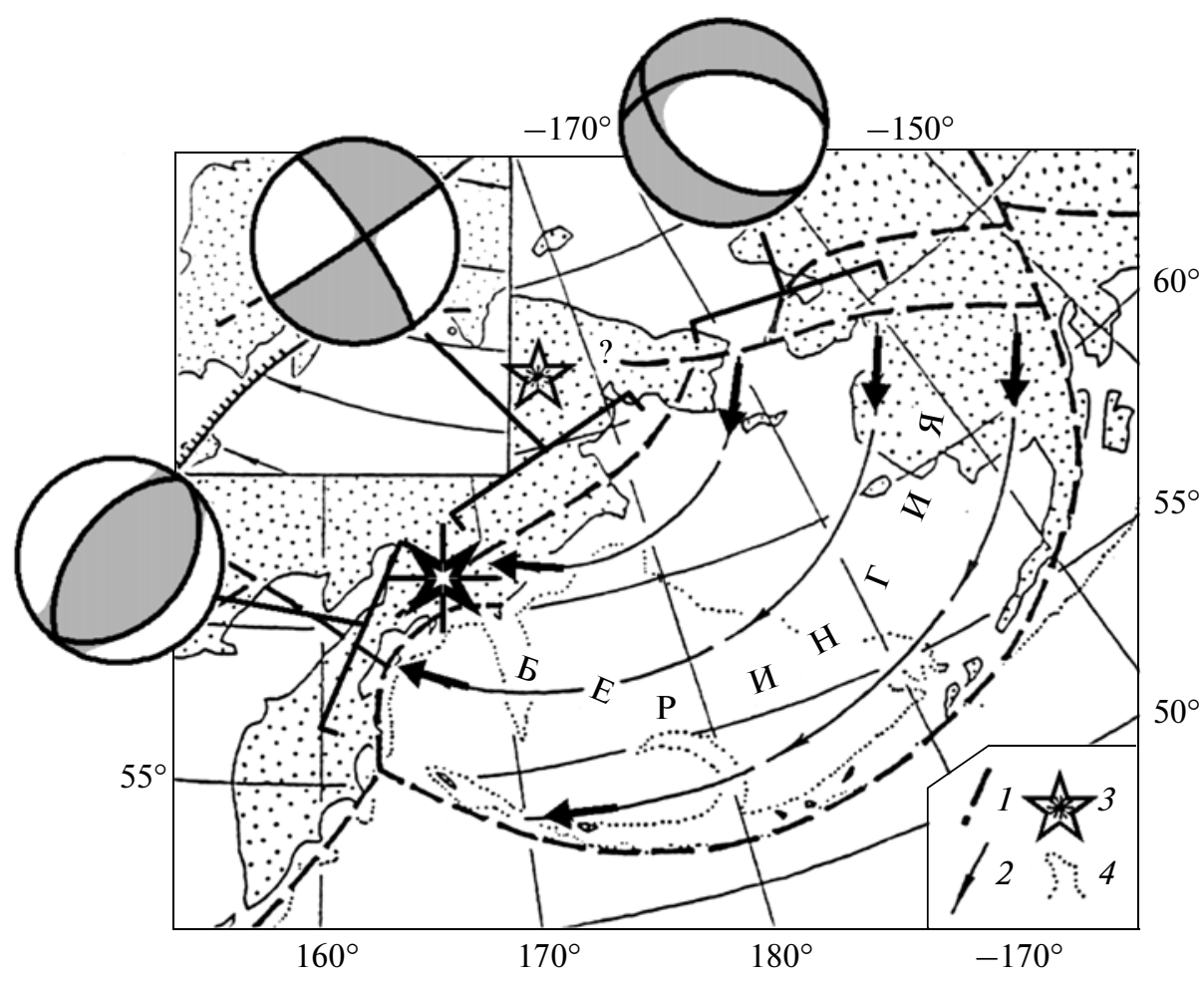

Рис. 3. Модель вращения Берингии относительно Северной Америки по данным механизмов землетрясений [Ландер и др., 1994]. Полюс вращения (показан серой звездой) $-67^{\circ} \mathrm{N} 176^{\circ} \mathrm{E}$, скорость вращения не определена. Средние механизмы землетрясений демонстрируют постепенную смену тектонических условий на северо-западной границе Беринги - от сжатия на юге Корякии, к сдвигам на Чукотке и растяжению на северо-западе Аляски. Черная звезда - эпицентр Олюторского землетрясения 21(22).04.2006.

\section{ЦУНАМИ В БЕРИНГОВОМ МОРЕ}

До недавнего времени считалось, что в Беринговом море не могут возникать сильные землетрясения и цунами. Однако события 12.11.1969, $M=7.8$ (Озерновское землетрясение) и 21(22).04.2006, $M=$ $=7.6$ (Олюторское землетрясение) заставили научную общественность пересмотреть свои взгляды на сейсмо- и цунамигенерирующий потенциал этого региона. В настоящее время возможность возникновения цунамигенных землетрясений в Беринговом море уже не вызывает сомнения, но остается практически не изученным вопрос о том, где именно могут быть расположены их очаги. Так как исторических данных о цунами практически нет, единственной возможностью это выяснить является изучение отложений цунами.

В ходе исследований, проводимых с 1999 г., были восстановлены параметры единственного исторического цунами 1969 г. на большом участке побережья - от полуострова Камчатского и о. Беринга на юге, до Укинского залива и о. Карагинского на севере [Martin et al., 2008; Pinegina, Kozhurin, 2011]. Таким образом, были получены параметры распределения высот цунами вдоль всего побережья, испытавшего воздействие волн свыше 3 м (рис. 4). Цунами
1969 г. служит ключевым событием, так как его интенсивность, магнитуда и протяженность охваченного им побережья позволяют примерно оценивать те же параметры для более древних событий.

На сегодняшний день в результате экспедиционных исследований отложений цунами получены данные для 85 пунктов Беринговоморского побережья Камчатки и о-ва Карагинский [Pinegina, Kozhurin, 2011]. В каждом пункте измерен топографический профиль, заложены и описаны геологические шурфы, рассчитаны высоты, дальности заплесков и повторяемость палеоцунами. Так, например, в южной части залива Озерной было выявлено до 14 цунамигенных горизонтов за последние $\sim 4.5$ тыс. лет [Bourgeois et al., 2006]. На о-ве Карагинский обнаружены 5 цунамигенных горизонтов за последние 1400-1800 лет [Pinegina, Kozhurin, 2011], верхний из которых соответствует цунами 1969 г. Однако этот горизонт был выявлен лишь в южной части острова.

Таким образом, было выяснено, что цунами, возникающие от очагов-аналогов 1969 г., не вызывают больших волн в центральной и северной части пролива Литке. Следовательно, отложения цунами здесь связаны с другими сейсмогенериру- 


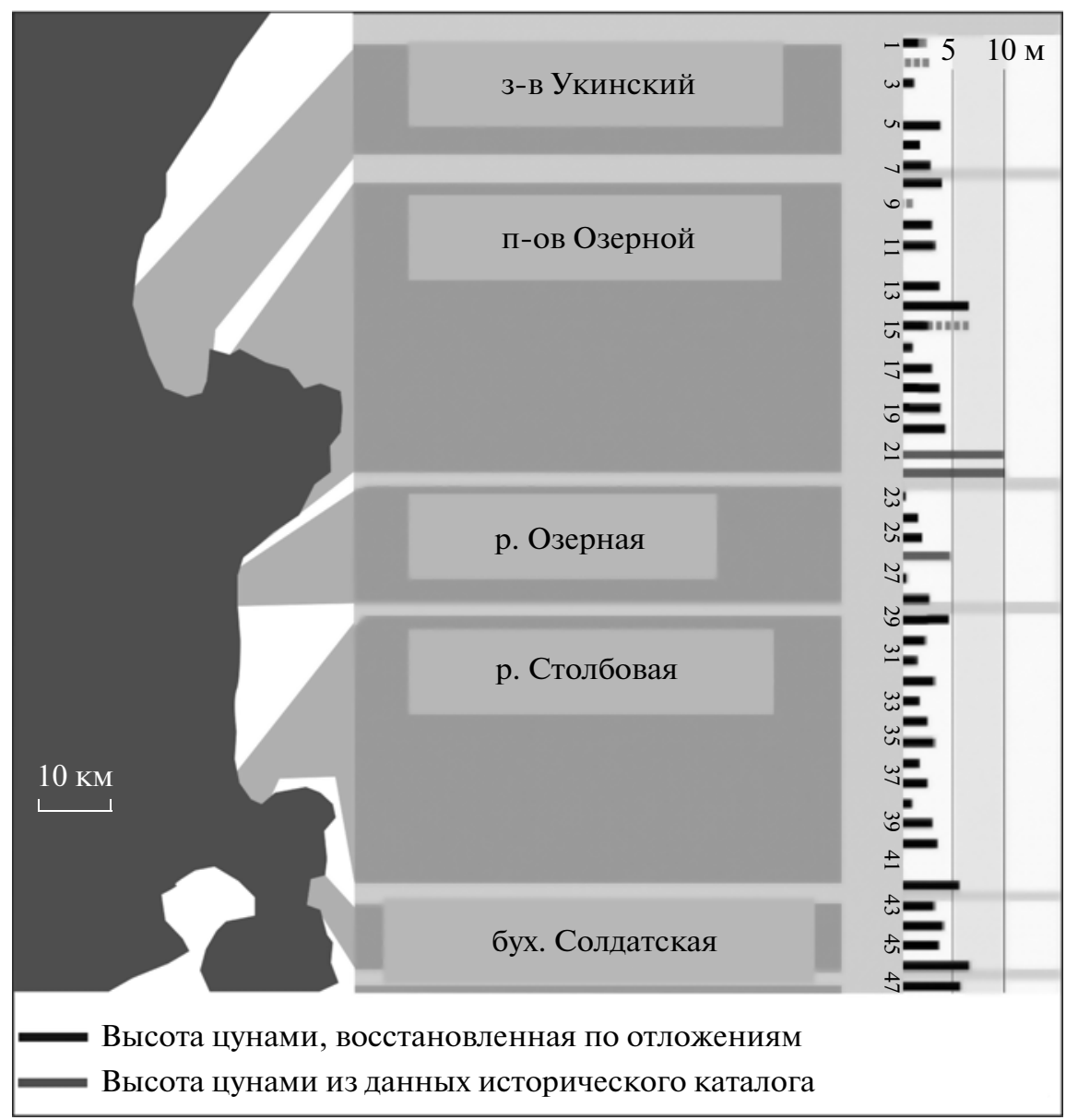

Рис. 4. Распределение вдоль берега высот цунами 1969 г., восстановленное по отложениям цунами (по [Martin et al., 2008]).

ющими очагами - либо в самом проливе Литке, либо к северу от о-ва Карагинский. В то же время, отложения цунами, обнаруженные на юге о-ва Карагинский, полуострове Озерной и в Укинском заливе, могут быть связаны с очагами землетрясений как непосредственно в проливе Литке, так и в заливе Озерной и в Командорской котловине. В северной части о-ва Карагинский выявлены 1-2 горизонта цунамигенных отложений с возрастом в пределах последних 1400-800 лет. На основе полученных палеосейсмологических данных была рассчитана повторяемость цунами с высотой $>3-5$ м для районов западного побережья Берингова моря (рис. 5).

Сравнение реконструированных параметров палеоцунами с параметрами цунами 1969 г. показывает, что за последние 2000 лет в Беринговом море не происходило землетрясений, намного превышавших по магнитуде землетрясение 1969 г. $(M w=7.8)$.

Основная особенность проявлений цунами в Беринговом море - относительно короткие горизонтальные заплески на суше (первые сотни мет- ров) и высоты в пределах 10 м. Однако они представляют реальную угрозу для населения, так как большинство поселков на побережье расположено на узких косах в устьях рек, на высоте 4-5 м над уровнем моря.

\section{АКТИВНЫЕ СЕЙСМО- \\ И ЦУНАМИГЕНЕРИРУЮЩИЕ РАЗЛОМЫ \\ НА ОБРАМЛЕНИИ КОМАНДОРСКОЙ КОТЛОВИНЫ БЕРИНГОВА МОРЯ}

В последние годы вдоль Беринговоморского побережья Камчатки, в Корякии и в районе Камчатско-Алеутского сочленения (р-н Камчатского полуострова) стали проводиться исследования активных разломов. Несомненно, Олюторское землетрясение 2006 г. послужило своеобразным “триггером”, спровоцировавшим особый интерес к активной тектонике региона. В результате к настоящему времени создана первая схема активных разрывных нарушений (рис. 6) [Кожурин, 2012; Кожурин, Пинегина, 2011]. По мере проведения исследований она совершенствуется и до- 


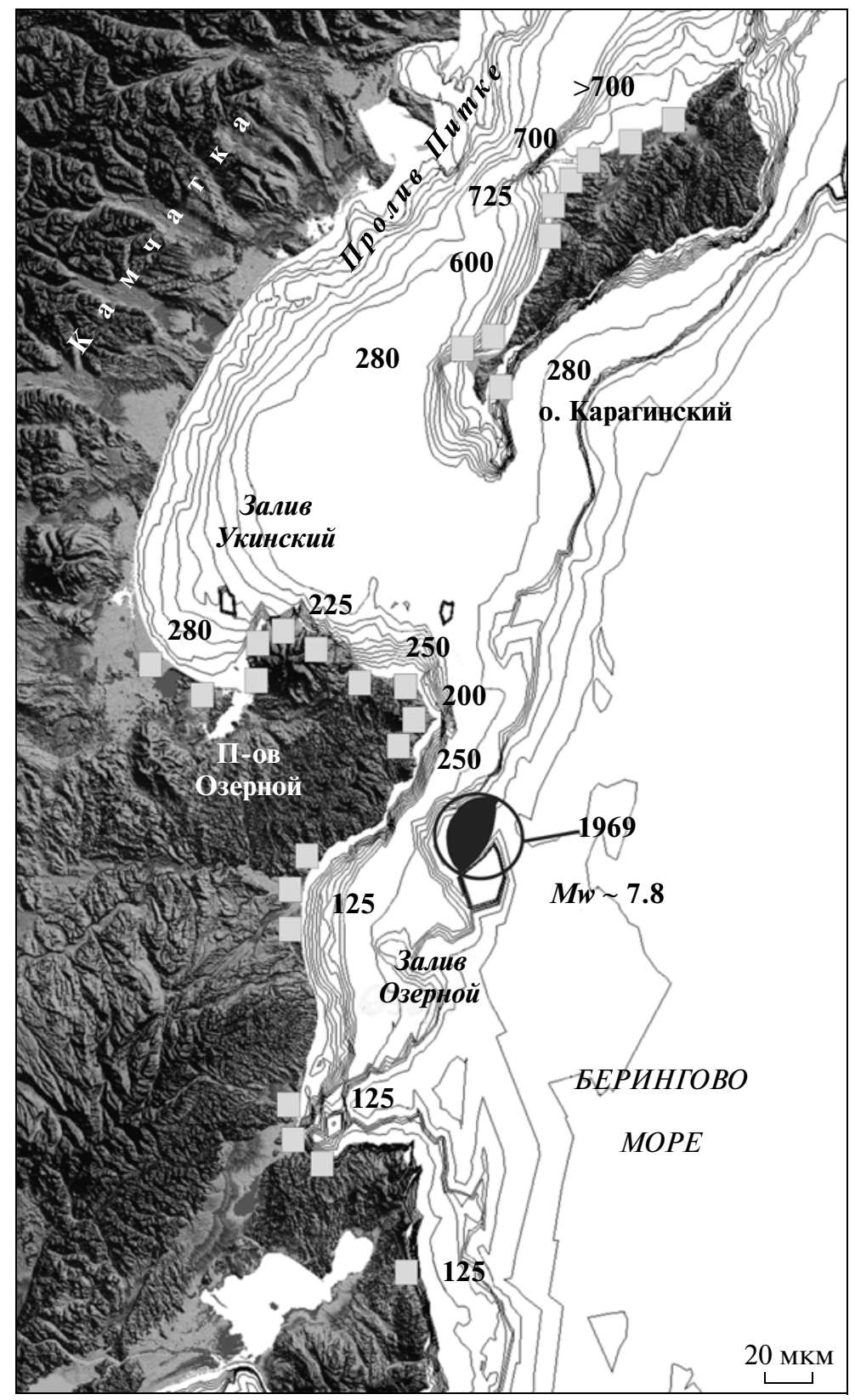

Рис. 5. Средняя повторяемость цунами (лет) с высотой $>3-5$ м в западном секторе Берингова моря за последние 2000 лет (по палеосейсмологическим данным) [Pinegina, Kozhurin, 2011]. Квадратиками показаны районы исследований, цифрами - повторяемость.

полняется. На основе полученных полевых данных была определена кинематика движений для ряда разломов, периоды повторяемости, средние амплитуды подвижек и длины разломов. На этой основе были определены механизмы возможных землетрясений (в том числе и цунамигенерирующих) и предварительно оценены максимальные протяженности очагов и их магнитуды. Эти данные необходимо использовать при обновлении схем сейсмоопасности, сейсмо- и цунамирайонирования.
Исследования показали [Кожурин, 2012; Pinegina, Kozhurin, 2011], что повторяемость подвижек по одному отдельно взятому разлому на обрамлении Берингова моря варьирует в пределах от первых тысяч лет до 10000 лет. Это объясняет то, почему активные разломы чаще всего не находят отражение в инструментальной сейсмичности. Повторяемость цунами от локальных источников в регионе составляет 125-700 лет. Таким образом, становится понятным, что большая часть активных разломов находится в акватории и еще не выявлена, так как из- 


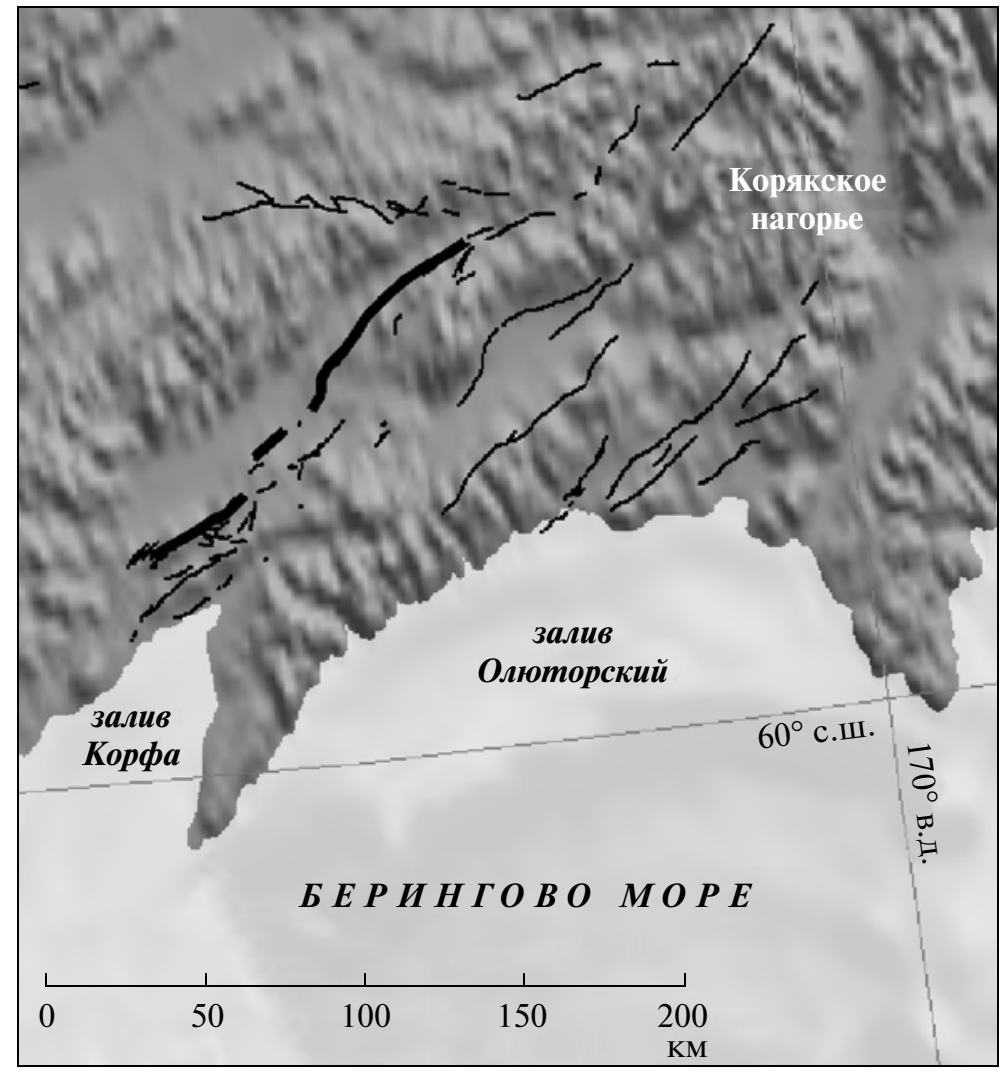

Рис. 6. Активные разломы (черные линии) на северо-западном обрамлении Берингова моря. Часть этих разломов может иметь продолжение в акватории и являться цунамигенерирующими. Сейсморазрыв очага Олюторского землетрясения 2006 г. показан жирной линией (по [Кожурин, 2012]).

вестные в настоящее время разломы при существующей повторяемости подвижек по ним не могут обеспечить такую повторяемость цунами.

\section{ЗАПАДНОЕ ОКОНЧАНИЕ АЛЕУТСКОЙ ДУГИ}

Тихоокеанская плита пододвигается под Камчатку со скоростью $~ 8$ см/год, проскальзывая по трансформному правосдвиговому разлому западного (Командорского) сегмента Алеутской зоны [Гордеев и др., 2001]. К границам Тихоокеанской плиты приурочены наиболее сильные землетрясения в районе. Один из главных вопросов - вероятность возникновения здесь, на крайнем западном отрезке Алеутской дуги, катастрофических землетрясений с магнитудами порядка 8.5-9 (рис. 7).

Имеющиеся данные позволяют сделать вывод о существовании на границе Берингийской $(\mathrm{Ce}-$ веро-Американской) и Тихоокеанской плит узкого вытянутого Командорского блока (Командорской микроплиты) [Apel et al., 2006]), зажатого между основными крыльями и перемещающегося вдоль границы с промежуточной по отношению к их движению скоростью. Это приводит к появлению между этими блоками косых (по отношению к главному простиранию) дислокаций. Рассматриваемая структура хорошо известна в зонах косой субдукции и иногда называется "щепкой” (sliver). Она является следствием продольного скольжения передовых блоков нависающей плиты вдоль главной границы, вызванного частичным сцеплением с погруженной плитой. Наиболее ярким представителем таких структур является огромная Бирманская микроплита (рис. 7) - щепка, подвижка которой привела к катастрофическому Суматранскому землетрясению 2004 г. Вероятно, что “щепка" Командорской микроплиты, перемещающаяся вдоль Алеутского желоба в сторону Камчатки, также рано или поздно может вызвать подобную катастрофу. Данное предположение особенно актуально, учитывая, что в последние десятилетия на юго-западной границе Командорской микроплиты наблюдается относительное сейсмическое затишье, в то время как ее северо-восточная граница остается более активной. Аналогичная картина наблюдалась и перед Суматранским землетрясением. 

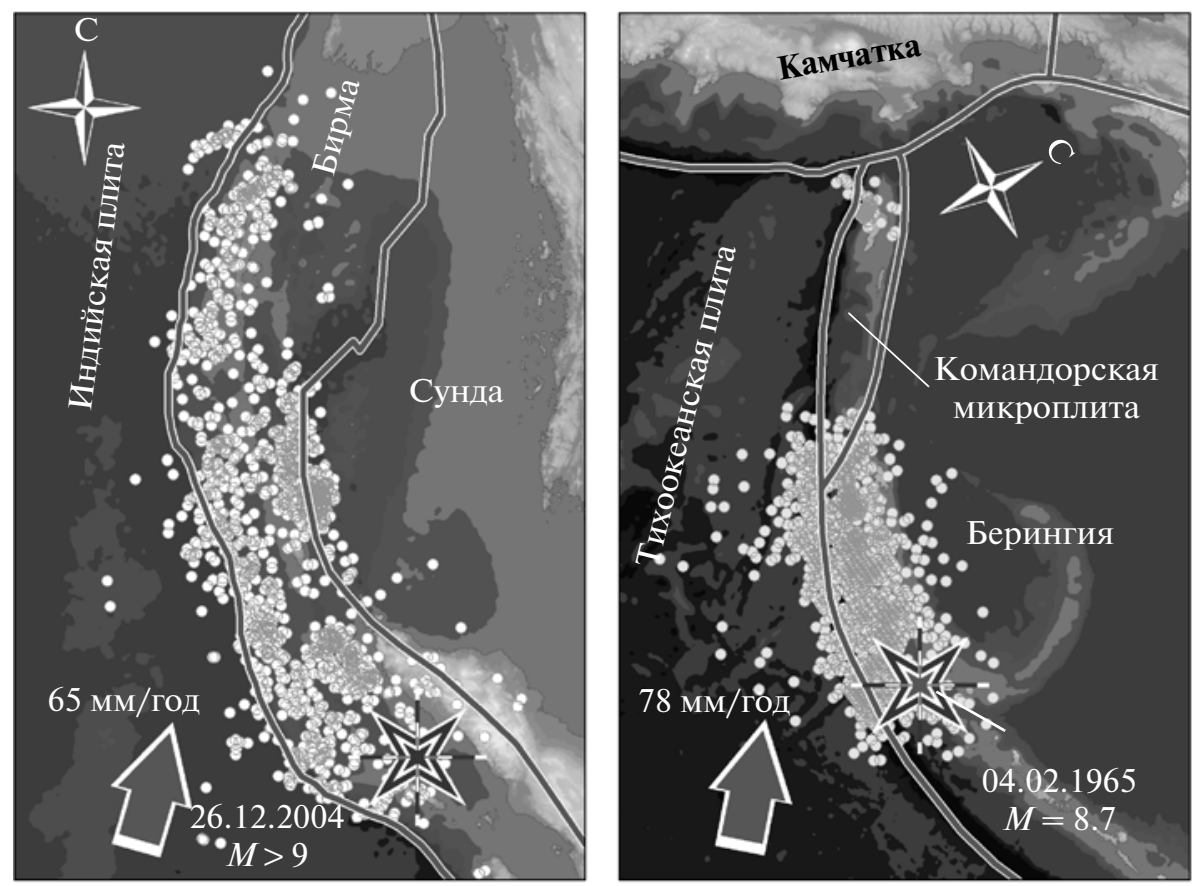

Рис. 7. Две “щепки”, возникающие при косом поддвиге различного масштаба (слева Бирманская, справа Командорская). Стрелки указывают относительное направление движения пододвигающейся плиты [Ландер, Пинегина, 2010]. Звездочками показаны эпицентры двух сильнейших землетрясений 1965 и 2004 гг., произошедших в сходных геодинамических обстановках.

В настоящее время не известны фактические данные, подтверждающие, что подобные события происходили здесь в прошлом. Вопрос требует детальных исследований, в том числе, палеосейсмологических.

\section{ЗОНА СОЧЛЕНЕНИЯ КАМЧАТСКОЙ И АЛЕУТСКОЙ ДУГ}

Район Камчатского полуострова, находящийся на продолжении Командорского блока, выступает в виде связующего звена между Алеутской и Камчатской островными дугами. В настоящее время общепринятым является предположение о том, что причиной деформации полуострова Камчатский является коллизионное взаимодействие Алеутской и Камчатской островных дуг [Watson and Fujita, 1985; Geist and Scholl, 1994; Mackey et al., 1997; Apel et al., 2006]. Камчатский полуостров уже на протяжении многих лет является объектом российских и международных исследований. Однако все еще нет однозначных ответов на вопросы о том, где именно находится коллизионный контакт дуг и каковы кинематические параметры коллизии. По существующим моделям, основной коллизионный контакт может находиться в Камчатском проливе, в подножии восточного подводного склона Камчатского полуострова [Geist, Scholl, 1994], или в пределах юго-восточной части полуострова Камчатский, которая в этом случае составляет единый блок с Командорской частью Алеут [Freitag et al., 2001; Gaedicke et al., 2000; Баранов и др., 2010], (рис. 8).

Возможным представляется и относительно свободное перемещение Камчатского полуострова относительно Командорского блока, с компонентой вращения по часовой стрелке, вызываемой неравномерным давлением на него продольных блоков западных Алеут, перемещающихся со скоростью, возрастающей в сторону Тихоокеанской плиты [Kozhurin, 2007]. В такой модели Западные Алеуты, включая полуостров Камчатский, движутся не как единый жесткий блок, а в виде набора относительно мелких блоков, способных до некоторой степени свободно перемещаться друг относительно друга. Доказано, что на Камчатском полуострове есть активные структуры, которые можно считать результатом коллизионного взаимодействия Камчатской и Алеутской дуг [Кожурин, Пинегина, 2011]. Наиболее западная из них, взбросо-надвиговой кинематики, протягивается в подножье восточного склона хр. Кумроч, разделяет собственно Камчатку и полуостров Камчатский и, в этом смысле, выступает в качестве главного коллизионного контакта двух дуг (рис. 8). 


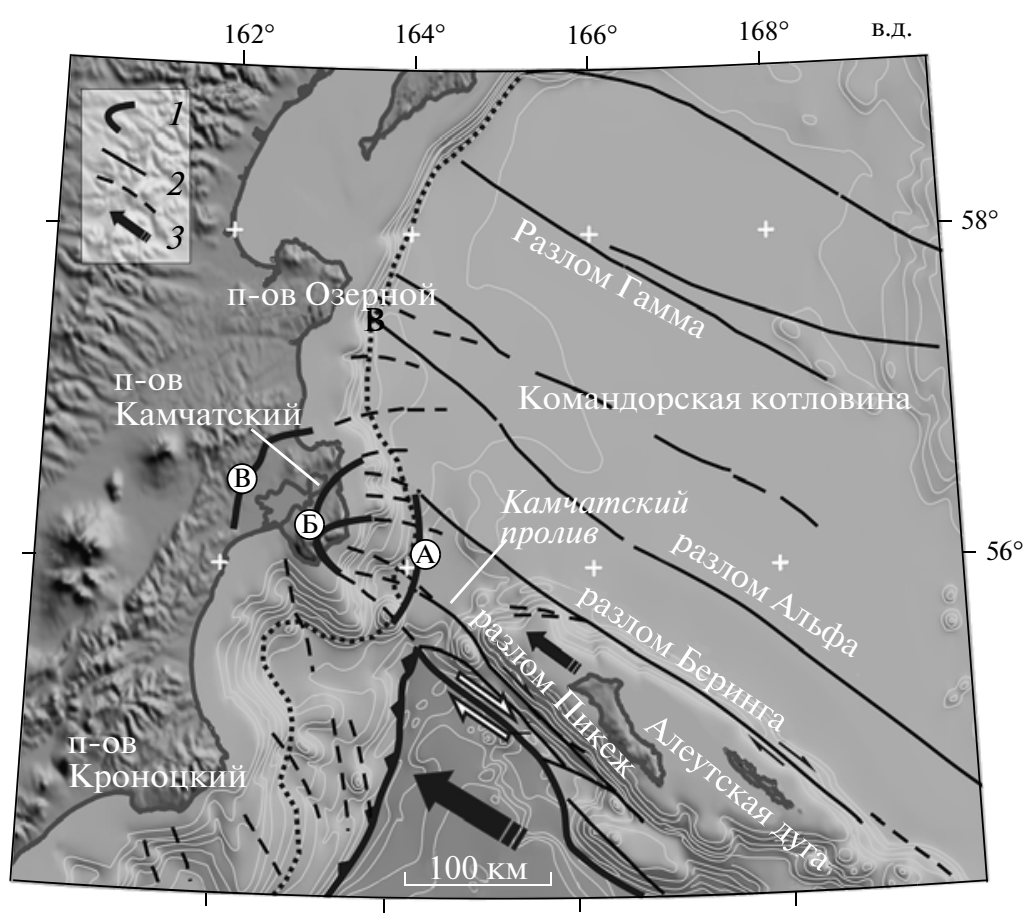

Рис. 8. Положение коллизионного контакта Алеутской дуги с Камчаткой по разным авторам: (А) - по [Geist, Scholl, 1994]; (Б) - по [Gaedike et al., 2000; Freitag et al., 2001; Баранов и др., 2010]; (В) - по [Кожурин и др., 2010]. Подводные разломы (пунктир - предполагаемые) показаны по [Селиверстов, 2009]. Черными стрелками показаны направления относительных движений Тихоокеанской плиты и Командорского блока.

\section{ВЫВОДЫ}

В представленном кратком обзоре рассмотрены лишь самые основные вопросы тектоники и сейсмичности Камчатско-Алеутско-Аляскинского региона, а также связанных с ними опасных природных процессов - сильных землетрясений и цунами. Беринговоморский регион сложен по своему тектоническому строению, при этом изученность тектонических и сейсмических процессов в нем остается до сих пор крайне низкой. Основные задачи, на которые должны быть направлены дальнейшие исследования, включают:

- доказательство или опровержение самого существования микроплиты Берингии и определение ее границ;

- получение данных о характере активных деформаций земной коры в континентальном обрамлении Берингова моря;

- выяснение деталей процесса коллизионного взаимодействия Алеутской и Камчатской дуг (тип, распределение и скорости коллизионных деформаций);

- поиск следов предшествующих мега-землетрясений на западной границе Алеутской дуги, в пределах Командорской “щепки”;

- определение положения вероятных очагов сильных (в т.ч. цунамигенных) землетрясений в Беринговом море и на его континентальном обрамлении;
- оценку повторяемости и магнитуд $M_{\max }$ землетрясений в Беринговоморском регионе, уточнение имеющихся карт сейсмо- и цунамиопасности и районирования.

\section{СПИСОК ЛИТЕРАТУРЫ}

Баранов Б.В., Гедике К., Фрейтаг Р., Дозорова К.А. Активные разломы юго-восточной части Камчатского полуострова и Командорская зона сдвига // Вестн. КРАУНЦ. Науки о Земле. 2010. № 2. Вып. № 16. C. 66-77.

Гордеев Е.И., Гусев А.А., Левина В.И., Леонов В.Л., Чебров В.Н. Коровая сейсмичность Камчатки. Комплексные сейсмологические и геофизические исследования Камчатки. Петропавловск-Камчатский. 2004. С. 62-74. Гордеев Е.И., Гусев А.А., Левин В.Е., Бахтиаров В.Ф., Павлов В.М., Чебров В.Н., Касахара М. Предварительный анализ перемещений станций GPS на Камчатке: скорости плит и геодезический предвестник землетрясения. Геодинамика и вулканизм Курило-Камчатской островодужной системы. Петропавловск-Камчатский. 2001. С. 82-94.

Землетрясения в СССР в 1962-1991 гг. М.: Наука. 1965-1997.

Каталог землетрясений Камчатки и Командорских островов 1962-2010. КФ ГС РАН. http://www.emsd.ru/ seismicity.html\#CATALOG

Кожурин А.И. Тихоокеанский тектонический пояс: общие черты структуры, кинематики, взаимоотношения с внутриконтинентальными подвижными поясами. 
Современная геодинамика Центральной Азии и опасные природные процессы: результаты исследований на количественной основе. Мат-лы Всерос. совещания и молодежной школы по совр. геодинамике. В 2-х т. Иркутск: ИЗК СО РАН. 2012. С. 140-145.

Кожурин А.И., Пинегина Т.К. Активная разломная тектоника полуострова Камчатский как проявление коллизии Камчатской и Алеутской островных дуг. Проблемы сейсмотектоники. Мат-лы XVI Международной конф. М. 2011. С. 260-263.

Кожурин А.И., Пономарева В.В., Пинегина Т.К. Деформация островной дуги, расположенной над краем погружающейся плиты: пример Камчатки. Матер. XLIII тектонического совещания: “Тектоника и геодинамика складчатых поясов и платформ фанерозоя”. 2010. T. 1. С. $319-323$.

Ландер А.В., Букчин Б.Г., Дрознин Д.В., Кирюшин А.В. Тектоническая позиция и очаговые параметры Хаилинского (Корякского) землетрясения 8 марта 1991 г: существует ли плита Берингия? // Вычислительная сейсмология. Вып. 26. М: Наука. 1994. С. 103-122.

Ландер А.В., Пинегина Т.К. Парадоксы очага Олюторского землетрясения 2006 г. - глубинная структура и динамика. Сб. тр. Второй региональной научно-технич. конф. "Проблемы комплексного геофизического мониторинга Дальнего Востока России” / Отв. ред. Чебров В.Н. Петропавловск-Камчатский: ГС РАН. 2010. С. 131-136.

Селиверстов Н.И. Геодинамика зоны сочленения Курило-Камчатской и Алеутской островных дуг. Петропавловск-Камчатский: изд-во КамГУ им. Витуса Беринга. 2009. 191 с.

Alaska Earthquake Information Center, http://giseis.alaska.edu/Seis/html_docs/db2catalog.html

Apel E.V., Bürgmann R., Steblov G., Vasilenko N., King R., Prytkov A. Independent active microplate tectonics of northeast Asia from GPS velocities and block modeling // Geophys. Res. Lett. 2006. V. 33. L11303. doi: 10.1029.

Bourgeois J., Pinegina T.K., Ponomareva V.V., Zaretskaia N.E. Holocene tsunamis in the southwestern Bering Sea, Russian Far East, and their tectonic implications // GSA bulletin. 2006. V. 118. № 3-4. P. 449-463.

Bulletin of the International Seismological Centre. 19642003, http://www.isc.ac.uk

Cross R.S., Freymueller J.T. Evidence for and implications of a Bering plate based on geodetic measurements from the Aleutians and western Alaska // J. Geophys. Res. V. 113. 2008. B07405, doi: 10.1029/2007JB005136.

Freitag R., Gaedicke C., Baranov B., Tsukanov N. Collisional processes at the junction of the Aleutian-Kamchatka arcs: new evidence from fission track analysis and field observations // Terra Nova. 2001. V. 13. P. 433-442.

Gaedicke C., Baranov B., Seliverstov N. et al. Structure of an active arc-continent collision area: the Aleutian-Kamchatka junction // Tectonophysics. 2000. V. 325. P. 63-85.

Geist, E.L. and Scholl, D.W. Large-scale deformation related to the collision of the Aleutian Arc with Kamchatka // Tectonics. 1994. V. 13. P. 538-560.

Global CMT catalog http://www.globalcmt.org/CMTsearch.html
Gordeev E.I., Gusev A.A., Levina V.I., Leonov V.L., Chebrov V.N. Shallow earthquakes in the Kamchatka Peninsula // J. Volcanology and Seismology. 2006. V. 3. P. 40-55.

Gordeev E.I., Gusev A.A., Levin V.E., Bakhtiarov V.F., Pavlov V.M., Chebrov V.N., Kasahara M. Preliminary analysis of deformation at the Eurasia-Pacific-North America plate junction from GPS data // Geophys. J. Int. 2001. V. 147. P. 189-198.

Gutenberg B., Richter C.F. Seismicity of the earth and associated phenomena. Princeton Univ. Press, Princeton. NJ. 1949. 273 p.

Kozhurin A.I. Active Faulting in the Kamchatsky Peninsula, Kamchatka-Aleutian Junction // American Geophysical Union, Geophysical Monograph Series "Volcanism and Subduction: The Kamchatka Region" / Eds: Eichelberger J., Gordeev E., Kasahara M. et al. 2007. V. 172. P. 263-282.

Lallemant A.H.G., Oldow J.S. Active displacement partitioning and arc-parallel extension of the Aleutian volcanic arc based on Global Positioning System geodesy and kinematic analysis // Geology. 2000. V. 28. № 8. P. 739-742.

Mackey K.G., Fujita K., Gunbina L.V., Kovalev V.N., Imaev V.S., Kozmin B.M., and Imaeva L.P. Seismicity of the Bering Strait region: evidence for a Bering block // Geology. 1997. V. 25. P. 979-982.

Mackey K.G., Fujita K., Hartse H.E., Stead R.J., Steck L.K., Gunbina L.V., Leyshuk N., Shibaev S.V., Koz'min B.M., Imaev V.S., Gordeev E.I., Chebrov V.N., Masal'ski O.K., Gileva N.A., Bormatov V.A., Voitenok A.A., Levin Y.N., and Fokina T.A. Seismicity map of eastern Russia, 19602010 // Seismological Res. Lett. 2010. V. 81. P. 761-768.

Martin M.E., Weiss R., Bourgeois J., Pinegina T.K., Houston H., Titov V.V. Combining constraints from tsunami modeling and sedimentology to untangle the 1969 Ozernoi and 1971 Kamchatskii tsunamis // Geophys. Res. Lett. 2008. V. 35. L01610.

Pinegina T., Kozhurin A. Tsunami and active tectonics along the western margin of the Bering Sea: impact on the coastal zone environment and evolution. Abstract on 2nd Bilateral Workshop of KALMAR- Phase I: Kurile-Kamchatka and the Aleutian Marginal Sea-Island Arc Systems, 16-20 May, Trier, Germany. 2011. P. 1-3.

Redfield T.F., Scholl D.W., Fitzgerald P.G., Beck E, Myrl Jr. Escape tectonics and the extrusion of Alaska: Past, present, and future // Geology. 2007. V. 35. № 11. P. 1039-1042.

Scholl D.W. Viewing the Tectonic Evolution of the Kamchatka-Aleutian (Kat) Connection With an Alaska Crustal Extrusion Perspective. American Geophysical Union, Geophysical Monograph Series "Volcanism and Subduction: The Kamchatka Region". Eds: Eichelberger J., Gordeev E., Kasahara M. et al. 2007. V. 172. P. 7-40.

USGS National Earthquake Information Centre http://neic.usgs.gov/neis/epic/epic.html

Watson F.F., Fujita K. Tectonic evolution of Kamchatka and the Sea of Okhotsk and implications for the Pacific Basin. Tectonostratigraphic terranes of the Circum-Pacific Region: Circum-Pacific Council for Energy and Mineral Resources, Earth Science Series. Editor Howell D.G. 1985. V. 1. P. 333-348. 